\title{
Numerical simulation of off-gas formation during top-blown oxygen converter steelmaking
}

\author{
Sen Li, Xiaolin Wei ${ }^{*}$, Lixin Yu \\ Institute of Mechanics, Chinese Academy of Sciences, No. 15 Beisihuanxi Road, Beijing 100190, China
}

\section{A R T I C L E I N F O}

\section{Article history:}

Received 13 October 2009

Received in revised form 11 January 2011

Accepted 12 January 2011

Available online 26 January 2011

\section{Keywords:}

Numerical simulation

Converter off-gas

Concentration

Flowrate

Sensible heat flux

\begin{abstract}
A B S T R A C T
In top-blown oxygen converter steelmaking process, a large amount of high-temperature off-gas is produced, and the off-gas is a precious valuable fuel containing high concentration of carbon monoxide (CO). Numerical model is developed for top-blown oxygen converter off-gas formation, the off-gas formation is simulated using the developed model, and the influences of the operating model of converter on the characteristics of off-gas (concentrations, temperature, flowrate and sensible heat flux) are investigated. The simulated results indicate that CO concentration varies gently, CO concentration can reach about $80 \%$ during 10-80\% blowing oxygen time, the change trend of $\mathrm{CO}_{2}$ concentration is contrary to that of $\mathrm{CO}$ concentration during 0-90\% blowing oxygen time, and the dramatic changes of oxygen lance height result in significant fluctuations of off-gas flowrate. The operation model of oxygen-blowing pressure significantly affects off-gas sensible heat flux, and the sensible heat flux is high during $40-80 \%$ blowing oxygen time.
\end{abstract}

(c) 2011 Elsevier Ltd All rights reserved.

\section{Introduction}

Oxygen blown converter steelmaking has developed for over 50 years, and the process is retaining its predominance as the world's No.1 steelmaking method by technological innovation [1]. Oxygen blown converter is generally divided into top-blowing, bottom-blowing and mixed blowing. Top-blown oxygen steelmaking produces $85.5 \%$ of steel made by converter [2]. A characteristic of converter production is the formation of a large amount of offgas. Converter off-gas is a precious valuable fuel containing about $80 \%$ carbon monoxide (CO) during the period of high gas production. Off-gas has a large amount of sensible heat, and its temperature at the converter outlet can reach $1450-1700{ }^{\circ} \mathrm{C}$ [3]. Converter off-gas is an important secondary energy resource for steel enterprises. Therefore, it is important for steel enterprises to effectively recover converter off-gas and its sensible heat.

With the sharp rise in energy costs, strenuous efforts have been made in development of new technique. Improving the recovery systems of converter off-gas and its sensible heat can effectively reduce the production cost of steelmaking, laying the basis for energy-saving steelmaking, and can remarkably decrease the total quantities of pollutant emissions to realize cleaner production. However, most of off-gas sensible heat becomes waste in spite of its large potential [4,5], mainly because of the intermittent discharge, the frequent change of composition concentrations, and the possibility of the explosion [6]. To ensure the safety of off-

\footnotetext{
* Corresponding author. Tel.: +86 1082544231

E-mail addresses: lisen@imech.ac.cn (S. Li), xlwei@imech.ac.cn (X. Wei).
}

gas recovery and consider the requirement of off-gas quality by users, the relevant restricted conditions must be set [7]. The sensible heat of converter off-gas is often utilized by cooling stack or waste heat boiler. Owing to the frequent fluctuations of temperature and flowrate of converter off-gas during steelmaking, the operational parameters of hot water or stream cooling circuit of stack and waste heat boiler fluctuate correspondingly, and the fatigue breakdown of heating surfaces easily occurs. Therefore, the change characteristics of converter off-gas during steelmaking are important for the improvement of converter off-gas recovery and its sensible heat utilization.

In the past decades, most researchers have developed mathematical models for modeling the impurity content in molten metal bath of oxygen converter, two-phase turbulent flow in the cavity without chemical reaction and post combustion of off-gas [8-15], but little work has focused on the simulation of converter off-gas formation. In order to improve the system of converter off-gas recovery and sensible utilization, the process model development for predicting the converter off-gas formation is very necessary. In this paper, numerical model is focused on the off-gas formation of the oxygen top-blown converter. Converter off-gas formation during blowing oxygen steelmaking is modeled, and the change characteristics of off-gas (concentrations, temperature, flowrate and sensible heat flux) are investigated by numerical simulation.

\section{Process description of converter off-gas formation}

The main role of oxygen converter is to reduce the contents of carbon and other impurities of pig iron liquid through oxidation 
reactions by blowing oxygen [16]. The top-blown oxygen steelmaking process is autogenous: the required thermal energy is produced during the process. The converter is tilted and charged, first with scrap and then with the molten iron, and then returned to the upright position. The molten iron accounts for about $80 \%$ of the total charge, the rest consisting of steel scrap. A typical chemistry of molten iron charged into the converter is: $4 \% \mathrm{C}, 0.2-0.8 \% \mathrm{Si}$, $0.08-0.18 \% \mathrm{P}$, and $0.02-0.08 \% \mathrm{Mn}[16,17]$. The converter is set upright and a water-cooled oxygen lance is lowered down into it. High-purity oxygen is blown into converter vessel through the vertically oriented water-cooled lance. The oxygen lance blows 99\% purity oxygen onto the molten metal surface, igniting the carbon dissolved in the metal and burning it to form carbon monoxide (CO) and carbon dioxide $\left(\mathrm{CO}_{2}\right)$, causing the temperature to rise to about $1700{ }^{\circ} \mathrm{C}$ [17]. This melts the scrap, lowers the carbon content of the molten iron and helps remove unwanted chemical elements. Fluxes (burnt lime or dolomite) are fed into the vessel to form slag which absorbs impurities of the steelmaking process. Typical capacities are 200-300 tons of liquid steel, and the tap-to-tap cycle is about 30-40 min with 13-18 min blowing oxygen period.

The top-blown oxygen steelmaking process is a very complex batch reaction course. Decarburization of molten metal is a basic process of oxygen converter steelmaking, and the process is determined by the development of heat and mass transfer processes in the bath [18-20]. For top-blown converter, the oxidization reactions of impurities mainly occur on the cavity surface of molten metal bath formed by top-blown oxygen and slag-metal interface, as shown in Fig. 1.

Carbon oxidation in molten metal bath is influenced by the temperature of molten metal bath and the element contents (such as carbon, silicon, manganese and phosphorus), and it produces carbon monoxide, and carbon monoxide usually reacts with excess oxygen in converter freeboard space to produce carbon dioxide, as shown in Fig. 1. In the meantime, small quantity of nitrogen is carried by oxygen jet stream. Therefore, the off-gas in the converter freeboard is mainly composed of $\mathrm{CO}, \mathrm{CO}_{2}, \mathrm{~N}_{2}$ and $\mathrm{O}_{2}$.

\section{Mathematic model off-gas formation}

The area calculation of cavity surface and slag-metal interface, kinetic model of the reactions of cavity surface and the kinetic model of the reactions of slag-metal interface are given in the supplementary materials.
The impurity removal reactions mainly occur on the cavity surface of molten metal bath and slag-metal interface. The cavity surface is important to decarburize and remove silicon from the molten metal, and the demanganization and dephosphorization reactions occur not only on the cavity surface but also on slag-metal interface, as shown in Fig. 1. During oxygen converter steelmaking, the oxygen is delivered into the converter by a top lance, which terminates in a fitting that contains several Laval nozzles. Each nozzle produces a jet at approximately twice the speed of sound, and the jet penetrates deeply into the molten metal and creates oscillation blowing cavity [21], as shown in Fig. 2. The shape and area of the cavity surface are related with the oxygenblowing pressure $\left(p_{0}\right)$, oxygen lance height $(L)$, the diameter of oxygen lance nozzle $\left(d_{1}\right)$ and nozzle number $\left(n_{z}\right)$. Oxygen lance height is the distance between oxygen lance nozzle tip and molten metal liquid level, as shown in Fig. 2. The area calculation of the cavity surface area can be referred to references $[8,22,23]$, and the area calculation of the slag-metal interface can be referred to reference [23].

When oxygen is injected into converter through a vertical lance, the oxygen is adsorbed on the cavity surface and diffuses into the molten metal liquid. The solvent oxygen can react with $\mathrm{C}, \mathrm{Si}, \mathrm{Fe}, \mathrm{Mn}$ and $\mathrm{P}$ in molten metal bath, and a series of oxidation reactions occurs, as show in Fig. 1. The kinetic model of the reactions of cavity surface can be referred to reference [24].

For oxygen top-blown converter, the reactions of demanganization and dephosphorization mostly occur on slag-metal interface [22]. The oxidation reactions on slag-metal interface are very complex, and these reactions are coupled, as shown in Fig. 1. The kinetic model of the reactions of slag-metal interface can be referred to Ref. [22].

It is assumed that the oxidizations of carbon and silicon in molten metal liquid only occur on the cavity surface, and that the oxidizations of manganese and phosphorous occur not only on the cavity surface but also on slag-metal interface. The model of the change of element (C, Si, Fe and P) concentration in molten metal liquid in molten metal bath during blowing oxygen can be referred to references [14,24].

Oxygen blown is mostly absorbed by molten metal bath to decarbonize, and then a large amount of carbon monoxide is produced and enters into converter off-gas. Secondary combustion of $\mathrm{CO}$ with $\mathrm{O}_{2}$ occurs in converter freeboard space, and it is assumed that the combustion reaches instantaneous equilibrium:

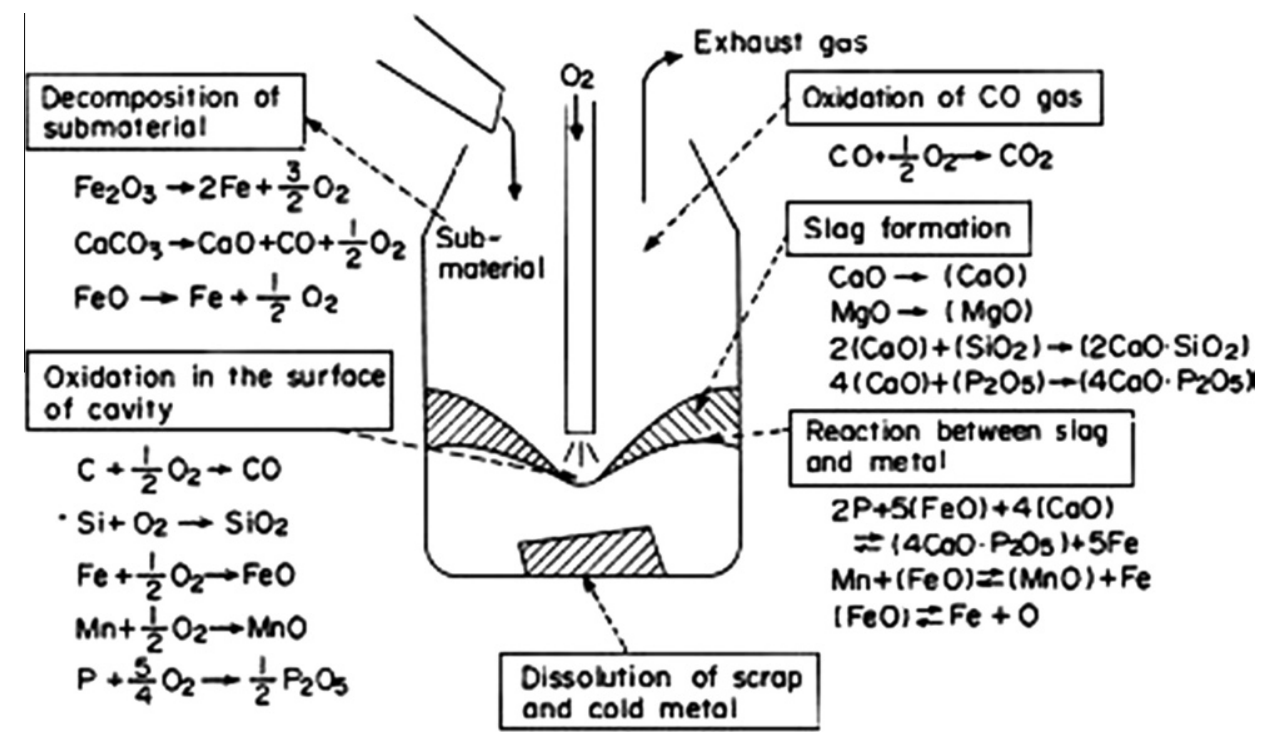

Fig. 1. Steelmaking using the oxygen top-blown converter $[18,19]$. 


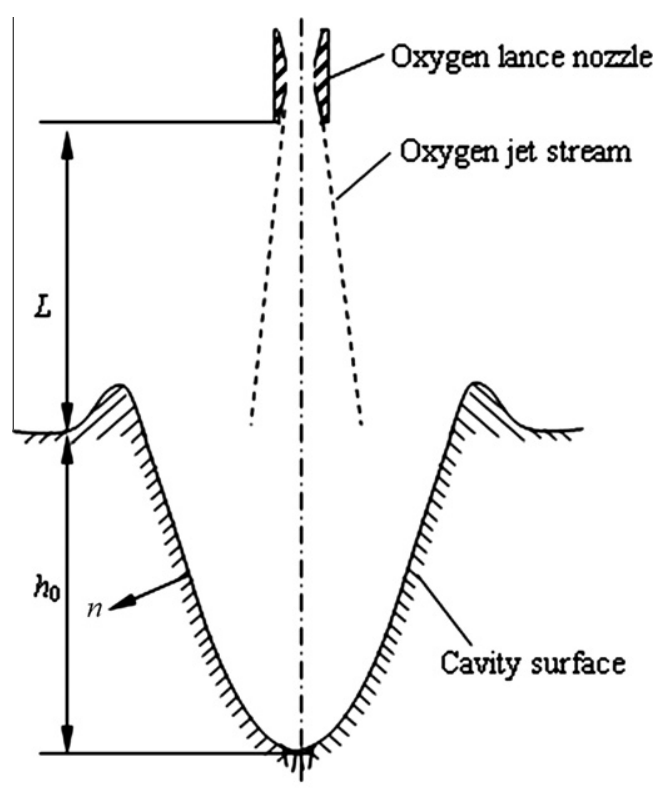

$L$ - Oxygen lance height, $h_{0}$ - Cavity depth

Fig. 2. The cavity formed by top-blown oxygen.

$\mathrm{CO}+1 / 2 \mathrm{O}_{2} \rightleftharpoons \mathrm{CO}_{2}$

It is assumed that: converter off-gas completely mixes; excess off-gas discharges through converter mouth in the blowing oxygen process; the oxidation reactions are controlled by mass transfer; CO consumption rate of above reaction is $R_{\text {co }}(\mathrm{mol} / \mathrm{s})$; the discharge amount of off-gas is $F_{\text {out }}(\mathrm{mol} / \mathrm{s})$; the total amount of off-gas in converter freeboard is $n_{v}(\mathrm{~mol})$; the mole numbers of $\mathrm{O}_{2}, \mathrm{CO}$ and $\mathrm{N}_{2}$ in off-gas are $n_{\mathrm{O}_{2}}, n_{\mathrm{CO}}, n_{\mathrm{CO}_{2}}$ and $n_{\mathrm{N}_{2}}$, respectively. The amount of oxygen blown is $Q_{\mathrm{O}_{2}}\left(\mathrm{~m}^{3} / \mathrm{s}\right)$, the concentration of $\mathrm{N}_{2}$ in oxygen blown is $\left[\mathrm{N}_{2}\right]$ (\%), and then the residual oxygen flux after the oxidation of impurities in molten metal bath $\left(F_{\mathrm{O}_{2}}\right)(\mathrm{mol} / \mathrm{s})$ according to the oxidization reactions of $\mathrm{C}, \mathrm{Si}, \mathrm{Mn}, \mathrm{P}$ and $\mathrm{Fe}$ (see Fig. 1 ) is

$$
\begin{aligned}
F_{\mathrm{O}_{2}}= & \frac{Q_{\mathrm{O}_{2}} \times 100-\left[\mathrm{N}_{2}\right] \times 1000}{100 \times 22.4}-\left[\frac{d\left(W_{\mathrm{m}} C_{[\mathrm{C}]}^{b}\right)}{d t}\right] \\
& -2\left[\frac{d\left(W_{\mathrm{m}} C_{[\mathrm{Si}]}^{b}\right)}{d t}\right]-\left[\frac{d\left(W_{\mathrm{m}} C_{[\mathrm{Mn}]}^{b}\right)}{d t}\right]-\frac{5}{2}\left(\frac{d\left(W_{\mathrm{m}} C_{[\mathrm{P}]}^{b}\right)}{d t}\right) \\
& -\left(\frac{d\left(W_{\mathrm{m}} C_{[\mathrm{Fe}]}^{b}\right)}{d t}\right)
\end{aligned}
$$

where $W_{\mathrm{m}}$ is the mass of molten metal liquid, $\mathrm{kg} ; C_{[\mathrm{i}]}^{b}$ is $i$ element concentration in molten metal liquid ( $i=\mathrm{C}, \mathrm{Si}, \mathrm{Fe}, \mathrm{P}), \mathrm{kmol} / \mathrm{kg}(\mathrm{Fe})$.

$\mathrm{CO}$ flux produced by decarburization reaction $\left(F_{\mathrm{CO}}, \mathrm{mol} / \mathrm{s}\right)$ is:

$F_{\mathrm{CO}}=\sigma_{\mathrm{C}} J_{\mathrm{O}} A_{\mathrm{C}}$

where $J_{\mathrm{O}}$ is the average diffusion flux of oxygen on the cavity surface, $\mathrm{mol} /\left(\mathrm{s} \mathrm{m}^{2}\right) ; A_{\mathrm{C}}$ is the area of cavity surface, $\mathrm{m}^{2} ; \sigma_{\mathrm{C}}$ is the consumption oxygen ratio of carbon oxidation reactions on the cavity. The calculations of $J_{\mathrm{O}}, A_{\mathrm{C}}$ and $\sigma_{\mathrm{C}}$ are given in the supplementary materials.

According to the mass equilibrium of converter off-gas, the changes of mole numbers of $\mathrm{O}_{2}, \mathrm{CO}$ and $\mathrm{N}_{2}$ in converter freeboard space are

$\frac{d n_{\mathrm{O}_{2}}}{d t}=F_{\mathrm{O}_{2}}-F_{\text {out }} \frac{n_{\mathrm{O}_{2}}}{n_{\mathrm{v}}}-\frac{R_{\mathrm{CO}}}{2}$

$\frac{d n_{\mathrm{CO}}}{d t}=F_{\mathrm{CO}}-F_{\text {out }} \frac{n_{\mathrm{CO}}}{n_{\mathrm{v}}}-R_{\mathrm{CO}}$ $\frac{d n_{\mathrm{CO}_{2}}}{d t}=-F_{\text {out }} \frac{n_{\mathrm{CO}_{2}}}{n_{\mathrm{v}}}+R_{\mathrm{CO}}$

$\frac{d n_{\mathrm{N}_{2}}}{d t}=-F_{\text {out }} \frac{n_{\mathrm{N}_{2}}}{n_{\mathrm{v}}}+\frac{Q_{\mathrm{O}_{2}}\left[\mathrm{~N}_{2}\right] \times 10}{22.4}$

$n_{\mathrm{v}}=n_{\mathrm{CO}_{2}}+n_{\mathrm{CO}}+n_{\mathrm{O}_{2}}+n_{\mathrm{N}_{2}}$

The converter off-gas is considered as ideal gas, and thus the total molar number of off-gas in converter freeboard space also can be expressed as:

According to the chemical equilibrium of $\mathrm{CO}$ and the material conservation in converter freeboard space, $\mathrm{CO}$ consumption rate $\left(R_{\mathrm{CO}}\right)$ and the molar flowrate of off-gas $\left(F_{\text {out }}\right)$ are respectively calculated as follows [22]:

$R_{\mathrm{CO}}=\frac{E-A \times D}{C+D \times B}$

$F_{\text {out }}=A+B \times R_{\mathrm{CO}}$

where

$A=\frac{T_{\mathrm{g}}+273}{2 T_{\mathrm{g}}+273}\left[F_{\mathrm{O}_{2}}+F_{\mathrm{CO}}+\frac{Q_{\mathrm{O}_{2}}\left[\% \mathrm{~N}_{2}\right] \times 10}{22.4}+\frac{q n_{m}}{F\left(T_{g}+273\right)}\right]$

$B=\frac{2\left(-\Delta H_{\mathrm{CO}}\right) n_{\mathrm{v}}-F\left(T_{\mathrm{g}}-273\right)}{2 F\left(2 T_{\mathrm{g}}+273\right)}$

$C=\frac{1}{n_{\mathrm{CO}_{2}}}+\frac{1}{n_{\mathrm{CO}}}+\frac{1}{4 n_{\mathrm{O}_{2}}}$

$D=\frac{1}{2 n_{\mathrm{v}}}$

$E=\frac{F_{\mathrm{CO}}}{n_{\mathrm{CO}}}+\frac{F_{\mathrm{O}_{2}}}{2 n_{\mathrm{O}_{2}}}$

$F=n_{\mathrm{O}_{2}} C_{\mathrm{PO}_{2}}+n_{\mathrm{CO}} C_{\mathrm{PCO}}+n_{\mathrm{CO}_{2}} C_{\mathrm{PCO}_{2}}+n_{\mathrm{N}_{2}} C_{\mathrm{PN}_{2}}$

where $C_{\mathrm{Pi}}$ is the gas specific heat $\left(i=\mathrm{O}_{2}, \mathrm{CO}, \mathrm{CO}_{2}, \mathrm{~N}_{2}\right), \mathrm{J}(\mathrm{mol} \mathrm{K})$.

According to the heat balance of converter off-gas, the change of off-gas temperature is calculated as follows:

$\frac{d T_{\mathrm{g}}}{d t}=\frac{q-\frac{F_{\text {out }}}{n_{\mathrm{v}}}\left(n_{\mathrm{O}_{2}} C_{\mathrm{PCO}_{2}}+n_{\mathrm{CO}} C_{\mathrm{PCO}}+n_{\mathrm{CO}_{2}} C_{\mathrm{PCO}_{2}}+n_{\mathrm{N}_{2}} C_{\mathrm{PN}_{2}}\right) T_{\mathrm{g}}+R_{\mathrm{CO}}\left(-\Delta H_{\mathrm{CO}}\right)}{n_{\mathrm{O}_{2}} C_{\mathrm{PO}_{2}}+n_{\mathrm{CO}} C_{\mathrm{PCO}}+n_{\mathrm{CO}_{2}} C_{\mathrm{PCO}_{2}}+n_{\mathrm{N}_{2}} C_{\mathrm{PN}_{2}}}$

where, $q$ is total heat amount absorbed by off-gas.

The model described above is used to simulate the converter off-gas formation of a 203 ton top-blown oxygen converter charged with molten pig iron and scrap. The parameters used in the model are shown in Table 1, the initial and boundary conditions are shown in Table 2. The main flow chart of calculation program is shown in Fig. 3.

\section{Model validation}

In the practical steelmaking process, since converter off-gas is high-temperature and entrains large amounts of molten dust (0.06-0.11 kg (dust)/kg (off-gas)), the composition concentrations of off-gas are hard to be monitored. The decarburization reaction is the key link in the off-gas formation, and the validation of the model is verified by the monitored decarburization rate and carbon content in molten metal bath.

In practical steelmaking process, converter off-gas is often discharged into the cooling stack to be partial combusted, cooled and dusted. In order to obtain the decarburization rate and carbon content in molten metal bath, off-gas sampling probe is installed on the highest point of the cooling stack, the location of tempera- 
Table 1

Model parameters in oxygen top-blown converter off-gas system.

\begin{tabular}{llll}
\hline Parameter & Value & Parameter & Value \\
\hline$k_{\mathrm{C}}$ & $1 \times 10^{12} \mathrm{~kg}[\mathrm{Fe}] /(\mathrm{kmol}[\mathrm{C}] \cdot \mathrm{s})$ & $\Delta H_{\mathrm{Si}}$ & $-817,682 \mathrm{~J} / \mathrm{mol}$ \\
$k_{\mathrm{Si}} / k_{\mathrm{C}}$ & $30 \mathrm{~kg}[\mathrm{C}] / \mathrm{kmol}[\mathrm{Si}]$ & $\Delta H_{\mathrm{Fe}}$ & $-722,432 \mathrm{~J} / \mathrm{mol}$ \\
$k_{\mathrm{Fe}} C_{\mathrm{Fe}}^{b} / k_{\mathrm{C}}$ & $1 \times 10^{-4} \mathrm{~kg}[\mathrm{C}] / \mathrm{kmol}[\mathrm{Fe}]$ & $\Delta H_{\mathrm{P}}$ & $-11,76,563 \mathrm{~J} / \mathrm{mol}$ \\
$k_{\mathrm{Si}} / k_{\mathrm{C}}$ & $1 \mathrm{~kg}[\mathrm{C}] / \mathrm{kmol}[\mathrm{Si}]$ & $\Delta H_{\mathrm{Mn}}$ & $-361,740 \mathrm{~J} / \mathrm{mol}$ \\
$k_{\mathrm{P}} / k_{\mathrm{C}}$ & $2 \mathrm{~kg}[\mathrm{C}] / \mathrm{kmol}[\mathrm{P}]$ & $\Delta H_{(\mathrm{CaO})}$ & $79.5 \mathrm{~kJ} / \mathrm{kg}$ \\
$t_{\mathrm{e}}$ & $1 \times 10^{-5} \mathrm{~s}$ & $\Delta H_{\mathrm{SC}}$ & $251.0 \mathrm{~kJ} / \mathrm{kg}$ \\
$h_{\mathrm{l}}$ & $41,800 \mathrm{~J} /\left(\mathrm{m}^{2} \mathrm{~s}^{\circ} \mathrm{C}\right)$ & $\mathrm{C}_{\mathrm{PO}_{2}}$ & $29.39 \mathrm{~J} /\left(\mathrm{mol}{ }^{\circ} \mathrm{C}\right)$ \\
$h_{\mathrm{g}}$ & $33,440 \mathrm{~J} /\left(\mathrm{m}^{2} \mathrm{~s}{ }^{\circ} \mathrm{C}\right)$ & $\mathrm{C}_{\mathrm{PCO}}$ & $29.33 \mathrm{~J} /\left(\mathrm{mol}^{\circ} \mathrm{C}\right)$ \\
$k_{\mathrm{m}}$ & $2 \times 10^{-3} \mathrm{~m} / \mathrm{s}$ & $\mathrm{C}_{\mathrm{PCO}_{2}}$ & $37.23 \mathrm{~J} /\left(\mathrm{mol}{ }^{\circ} \mathrm{C}\right)$ \\
$k_{\mathrm{s}}$ & $1 \times 10^{-4} \mathrm{~m} / \mathrm{s}$ & $\mathrm{C}_{\mathrm{PN}_{2}}$ & $20.8 \mathrm{~J} /\left(\mathrm{mol}{ }^{\circ} \mathrm{C}\right)$ \\
$k_{\mathrm{CaO}}$ & $1 \times 10^{-3} \mathrm{~m} / \mathrm{s}$ & $\rho_{\mathrm{m}}$ & $7020 \mathrm{~kg} / \mathrm{m}^{3}$ \\
$A_{\mathrm{sm}} k_{\mathrm{m}} \rho_{\mathrm{L}} / W_{\mathrm{m}}$ & $4.48 \times 10^{-3} 1 / \mathrm{s}$ & $\rho_{\mathrm{s}}$ & $3500 \mathrm{~kg} / \mathrm{m}^{3}$ \\
$\Delta H_{\mathrm{C}}$ & $-139,420 \mathrm{~J} / \mathrm{mol}$ & & \\
\hline
\end{tabular}

Table 2

The initial and boundary conditions.

\begin{tabular}{llll}
\hline Parameter & Value & Parameter & Value \\
\hline Molten pig iron & 203 ton & Blowing oxygen flowrate & $12-13 \mathrm{~m}^{3} / \mathrm{s}$ \\
Steel scrap & 30.4 ton & $\mathrm{N}_{2}$ concentration in oxygen blown & $1 \%$ \\
Carbon & $3.84 \mathrm{wt} \%$ & Diameter of lance nozzle & $0.047 \mathrm{~m}$ \\
Silicon & $0.38 \mathrm{wt} . \%$ & Lance nozzle number & 8 \\
Manganese & $0.322 \mathrm{wt} . \%$ & Total blowing oxygen time & $16 \mathrm{~min}$ \\
Phosphorus & $0.102 \mathrm{wt} . \%$ & Molten metal temperature & $1320^{\circ} \mathrm{C}$ \\
\hline
\end{tabular}

ture measurement is near the sampling probe of flue gas, and the flue gas flowrate is measured after off-gas dust. The concentrations of $\mathrm{CO}$ and $\mathrm{CO}_{2}$ in flue gas is continuously measured by gas mass spectrometer (EMG-20-1, the relative error is less than 0.5\%), temperature of flue gas is measured by Platinum-Rhodium thermocouples (the measurement accuracy is $\pm 1.5^{\circ} \mathrm{C}$ ), and the flue gas flowrate is measured by gas flow meter (Verabar 400). Based on the conservation of carbon, the decarburization rate of molten metal bath can be calculated as

$-\frac{d C}{d t}=Q_{\text {gas }} \times\left(\mathrm{CO} \%+\mathrm{CO}_{2} \%\right) \times \frac{12}{22.4} \times \frac{1}{W_{\mathrm{st}}}$

where $d C / d t$ is the decarburization rate,\%/s; $Q_{\text {gas }}$ is off-gas flowrate, $\mathrm{m}^{3} / \mathrm{s} ; \mathrm{CO} \%$ and $\mathrm{CO}_{2} \%$ are the concentrations of $\mathrm{CO}$ and $\mathrm{CO}_{2}$ in flue gas, respectively, \%; $W_{\mathrm{st}}$ is the mass of molten steel, $\mathrm{kg}$.

The carbon content in molten bath $(\mathrm{C} \%)$ can be calculated as:

$$
\mathrm{C} \%=\mathrm{C}_{0} \%-\int_{0}^{t} \mathrm{Q}_{\mathrm{gas}} \times\left(\mathrm{CO} \%+\mathrm{CO}_{2} \%\right) \times \frac{12}{22.4} \times \frac{1}{W_{\mathrm{st}}} d t
$$

where $\mathrm{C}_{0} \%$ is the initial carbon content, and $t$ is blowing oxygen time, $s$.

In order to express the time course of blowing oxygen, the percent of blowing oxygen time $(\tilde{t})$ is defined:

$\tilde{t}=\frac{t}{t_{\mathrm{T}}} \times 100 \%$

where $t$ is the blowing oxygen time, and $t_{T}$ is total blowing oxygen time. During practical blowing oxygen, the changes of oxygen lance height and oxygen-blowing pressure are shown in Fig. 4. As can be seen from Fig. 4, at the initial blowing oxygen, in order to ignite the carbon dissolved in molten metal, oxygen pressure and oxygen lance

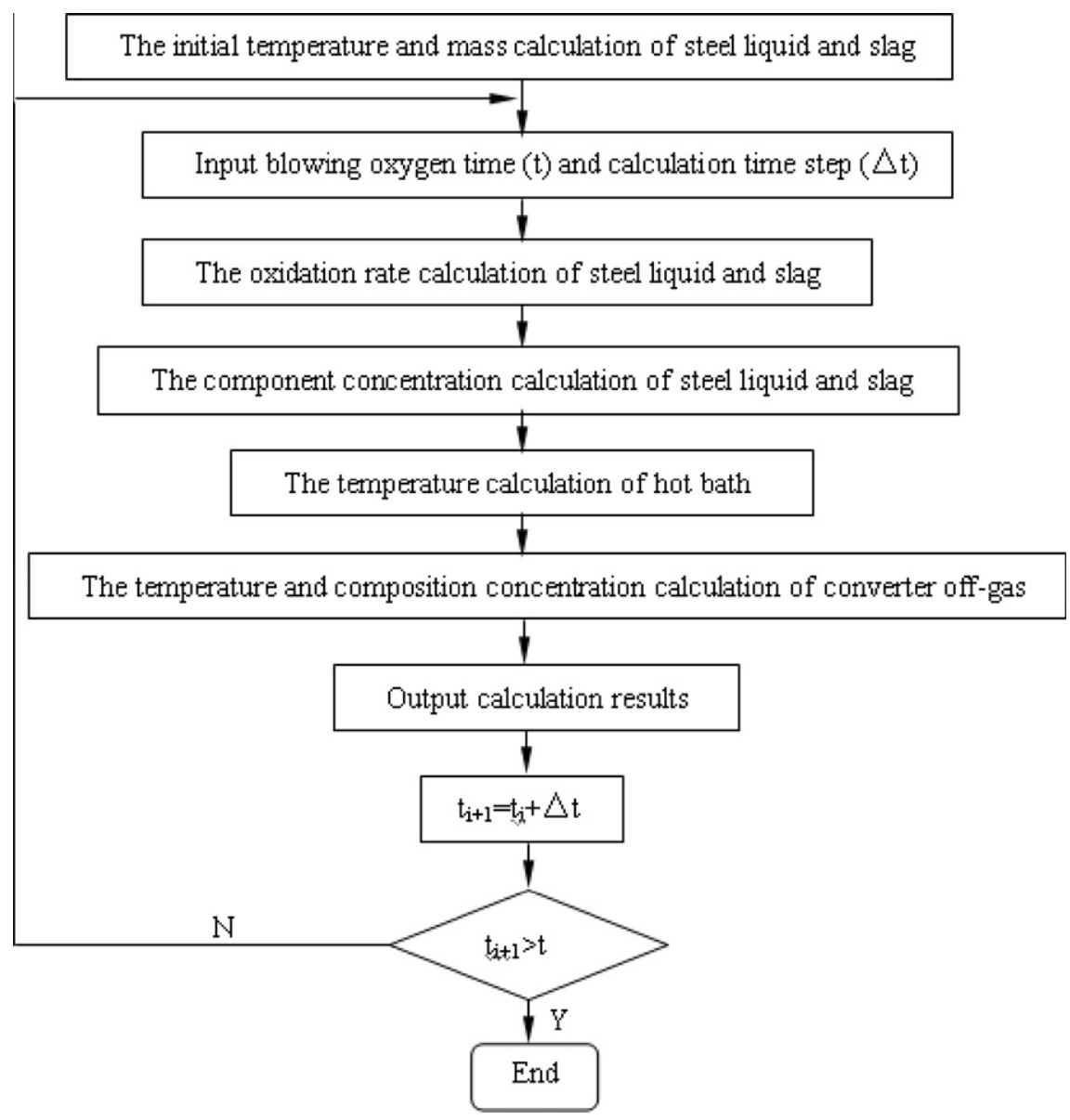

Fig. 3. The main flow chart of calculation program. 


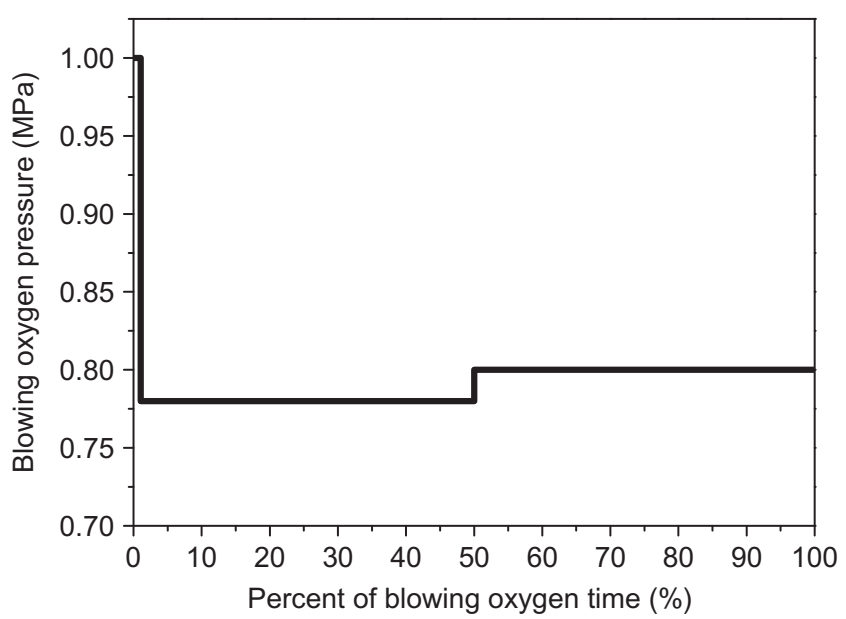

(a) Oxygen-blowing pressure

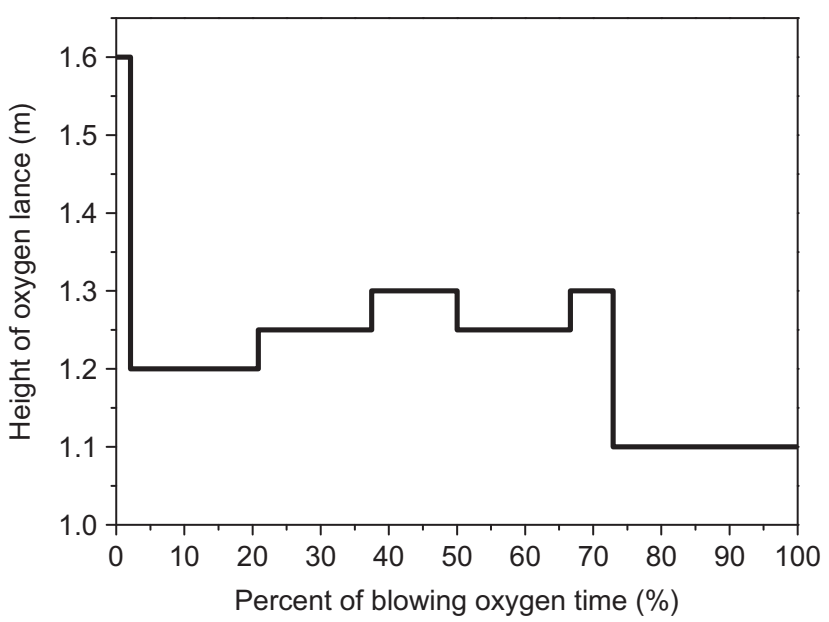

(b) Oxygen lance height

Fig. 4. The changes of oxygen lance height and blowing oxygen pressure.

height rapidly decrease from $1 \mathrm{MPa}$ to $0.78 \mathrm{MPa}$ and from $1.6 \mathrm{~m}$ to $1.2 \mathrm{~m}$, respectively; with the increase of blowing oxygen time, oxygen pressure and oxygen lance height are adjusted according to the change of carbon content in the molten metal bath; in order to achieve the carbon content required, oxygen lance height reaches the minimum to strengthen decarburization near the end of blowing oxygen time.

Fig. 5 shows the predicted and measured decarburization rate and carbon content in molten metal bath during blowing oxygen. As can be seen from Figs. 4 and 5, the decrease of oxygen pressure causes the decrease of decarburization rate at blowing oxygen time, and decreasing oxygen lance height makes decarburization rate increase.

The predicted values are in good agreement with measured values, and it indicates that the established model can reasonably simulate the production process of top-blown oxygen converter steelmaking.

\section{Simulation results and discussions of converter off-gas performances}

In the blowing oxygen process of converter steelmaking, the operational parameters of oxygen lance (oxygen lance height and oxygen-blowing pressure) influence decarburization rate, and the

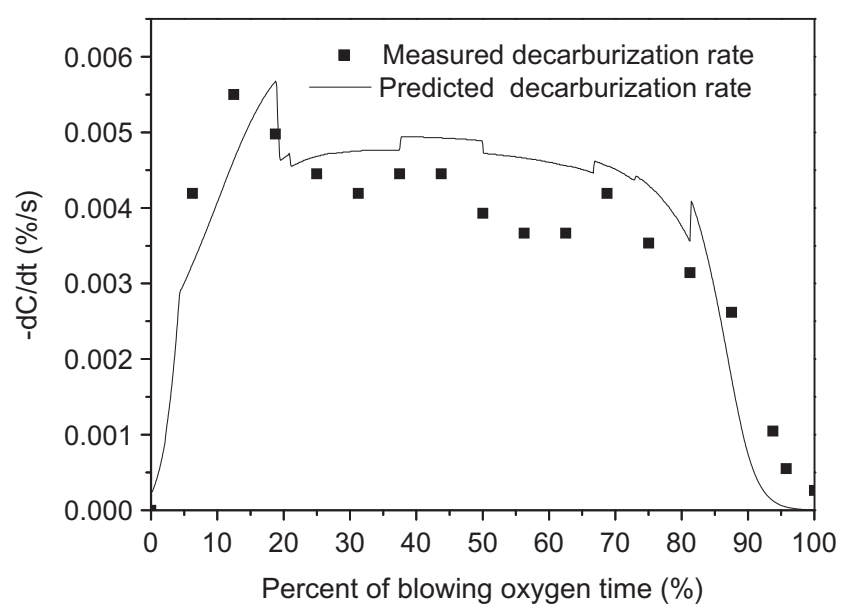

(a) The change of decarburization rate during blowing oxygen

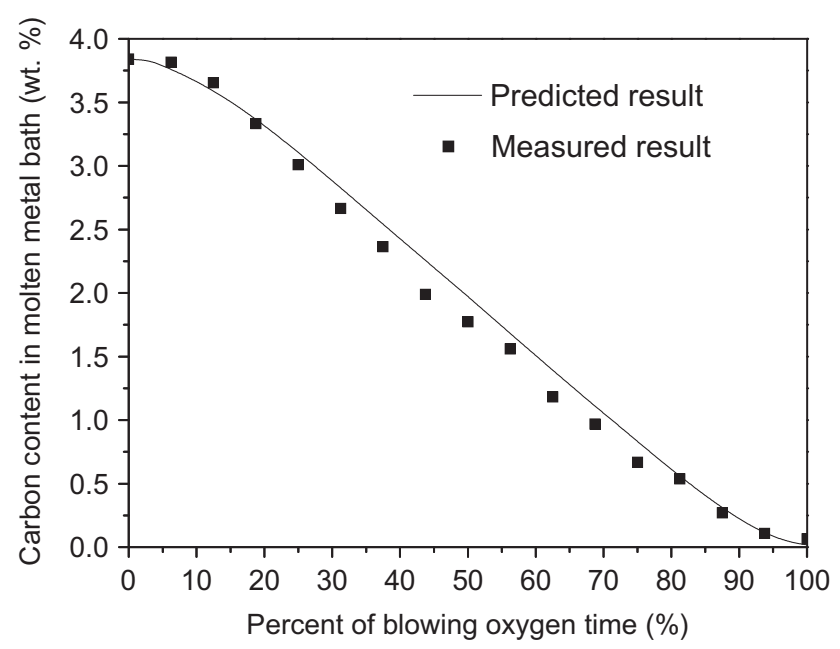

(b) The change of carbon content in molten metal bath during blowing oxygen

Fig. 5. Comparisons of predicted and measured decarburization rate and carbon content.

model developed is used to predict the influences of the operational parameters of oxygen lance on the converter off-gas performances including composition concentrations, temperature, flowrate and sensible heat flux. In practical steelmaking process, there are two operation models of oxygen lance: (1) adjustment of oxygen lance height at a constant oxygen-blowing pressure; (2) concurrent adjustment of oxygen lance height and oxygenblowing pressure. The effects of the above two operation models of oxygen lance on converter off-gas performances are investigated in the following sections.

5.1. The influences of oxygen lance height on off-gas performances at a constant oxygen-blowing pressure

A series of simulation calculations is performed to investigate the influence of oxygen lance height on converter off-gas formation at a constant oxygen-blowing pressure $(0.9 \mathrm{MPa})$. In the practical steelmaking process, in order to control slag forming, slag splashing, decarburization and metal bath temperature, the height of oxygen lance is frequently adjusted. Fig. 6 shows two conventional operation models of oxygen lance height during blowing oxygen. 
For operation model $\mathrm{A}$, the adjustment range of oxygen lance height is great, which may strengthen the disturbance of cavity surface during blowing oxygen. For operation model B, oxygen lance height gradually decreases during blowing oxygen, which may make the change of cavity surface gentle during blowing oxygen.

Fig. 7 shows the changes of off-gas composition concentrations during blowing oxygen under A and B operation models of oxygen lance height. The change trends of off-gas concentrations under two operation models of oxygen lance height are similar. The simulation results indicate: at the beginning of blowing oxygen, $\mathrm{CO}$ concentration is low, but it rapidly increases from $0 \%$ to $60 \%$ or so in the range of $0-10 \%$ blowing oxygen time; in the range of $10-80 \%$ blowing oxygen time, CO concentration varies gently, and its maximum can reach about $80 \%$; in the range of $80-100 \%$ blowing oxygen time, $\mathrm{CO}$ concentration rapidly decreases; the change trend of $\mathrm{CO}_{2}$ concentration is contrary to that of $\mathrm{CO}$ concentration in the range of $0-90 \%$ blowing oxygen time.

$\mathrm{CO}$ is formed by the oxidation of carbon in the molten metal bath, as shown in Fig. 1. The characteristic of carbon oxidation development is conditioned by the temperature and mass transfer processes in molten metal bath [20]. The temperature of molten metal bath at the start of blowing oxygen is low and not enough for the successful occurrence of decarburization despite the presence of a high concentration of carbon and rate of oxygen arrival. At this time, silicon and manganese, the concentration of which in metal determines the level of its saturation with oxygen, are energetically oxidized. Therefore, the decarburization rate is low, and $\mathrm{CO}$ formed is almost completely oxidized to $\mathrm{CO}_{2}$ in the converter freeboard space. The off-gas composition at this period, amounting to about $10 \%$ of the total duration of blowing oxygen,

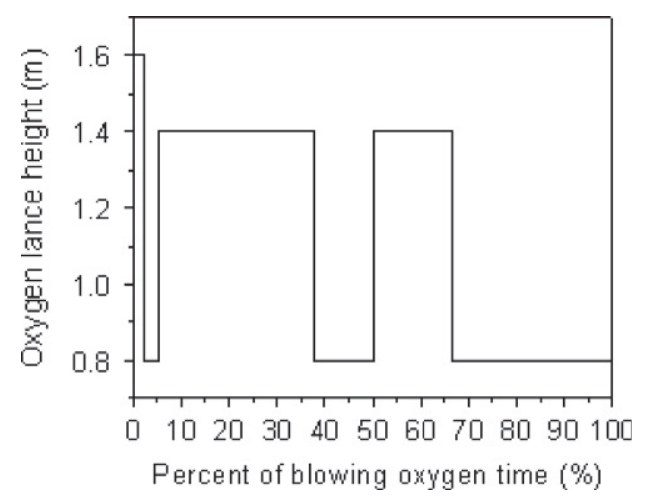

(a) Operation model A

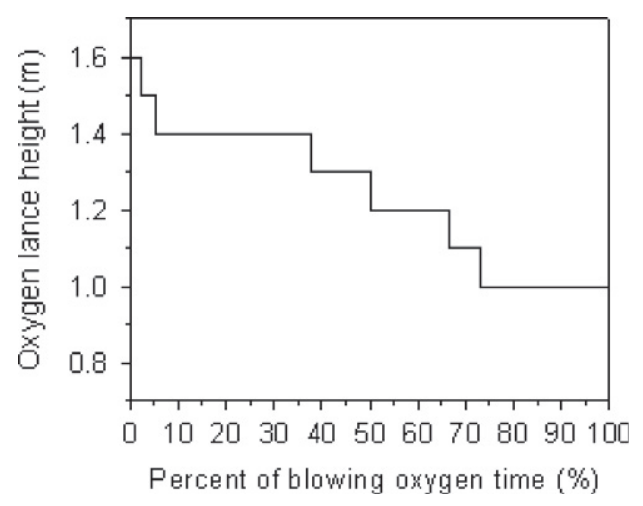

(b) Operation model B

Fig. 6. Operation models of oxygen lance height

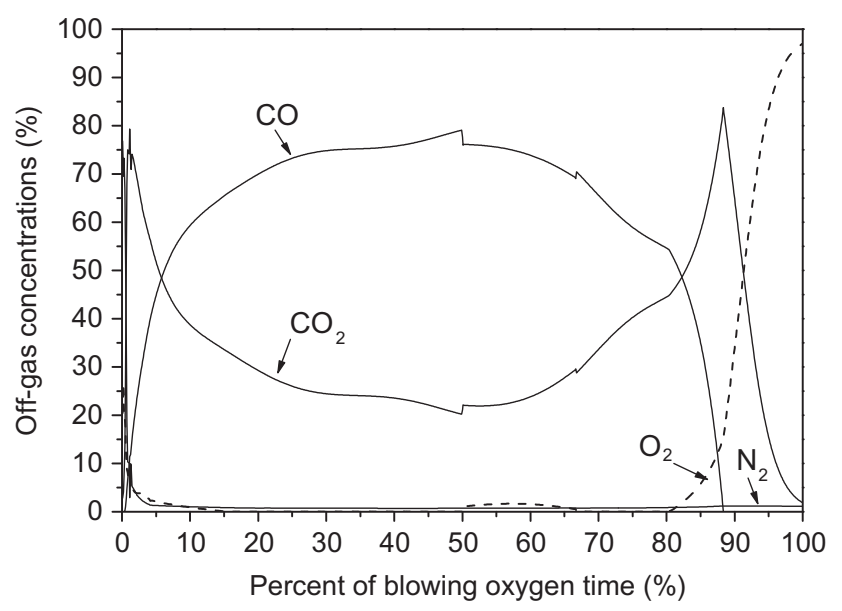

(a) Under operation model A

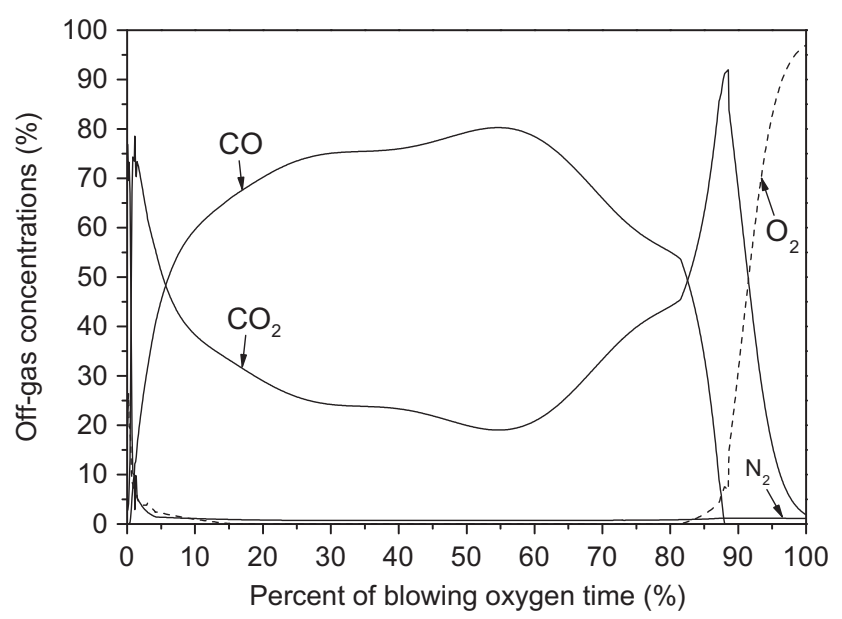

(b) Under operation model B

Fig. 7. The changes of converter off-gas concentrations during blowing oxygen.

is characterized by a rather high content of $\mathrm{CO}_{2}$ and low content of $\mathrm{CO}$. With the decrease of silicon and manganese levels in the molten metal bath, CO concentration increases rapidly. At this time, the temperature of molten metal bath is enough for decarburization, and decarburization reaction is stable. Therefore, the change of $\mathrm{CO}$ concentration is relatively stable, and CO concentration ranges from $60 \%$ to $80 \%$, amounting to about $70 \%$ of the total duration of blowing. In the converter freeboard, $\mathrm{CO}$ usually reacts with excess $\mathrm{O}_{2}$ to form $\mathrm{CO}_{2}$, and $\mathrm{CO}_{2}$ concentration ranges from $20 \%$ to $40 \%$ in the duration of blowing. At the end of blowing oxygen, owing to low carbon concentration in molten steel bath, the decarburization rate is low, and thus $\mathrm{CO}$ concentration decreases. In the meantime, there is a large amount of excess $\mathrm{O}_{2}$ in converter freeboard, $\mathrm{CO}$ can adequately react with excess $\mathrm{O}_{2}$ to form $\mathrm{CO}_{2}$, which makes $\mathrm{CO}_{2}$ concentration increase. With the further decrease of decarburization rate, $\mathrm{CO}$ is completely oxidized to form $\mathrm{CO}_{2}$. Therefore, in the range of $90-100 \%$ blowing oxygen time, $\mathrm{CO}$ concentration is zero, and the concentration $\mathrm{CO}_{2}$ rapidly decreases, as shown in Fig. 7.

In Fig. $7, \mathrm{O}_{2}$ concentration is larger than $1 \%$ in the ranges of $0-15 \%$ and $80-100 \%$ blowing oxygen time, which indicates that there is a large of excess $\mathrm{O}_{2}$ in converter off-gas and exists the possibility of the off-gas explosion in the off-gas recovery process. To ensure the safety of off-gas recovery and consider the requirement of off-gas quality by users, relevant restricted condition must be 
set. Whether the converter off-gas must be recovered depends on the concentrations of $\mathrm{CO}$ and $\mathrm{O}_{2}$ in off-gas. The converter off-gas recovery restricted condition is that $\mathrm{CO}$ concentration is greater than or equal to $40 \%$ while $\mathrm{O}_{2}$ concentration is less than $1 \%$. At the beginning and end of blowing oxygen, the concentrations of $\mathrm{CO}$ and $\mathrm{CO}_{2}$ can't meet the requirement of off-gas recovery. At this time, in order to ensure safety of off-gas recovery, a large amount of air enters into the interspace between the mobile smoke cover raised and the converter mouth, and off-gas combusts in cooling stack or waste heat boiler without recovery.

In Fig. $7, \mathrm{~N}_{2}$ concentration rapidly decreases from $79 \%$ to about $1 \%$ at the beginning of blowing oxygen, and then it keeps very low. $\mathrm{N}_{2}$ in off-gas at the start of blowing oxygen originates from initial air of converter freeboard. With the increase of blowing oxygen time, the residual air in converter freeboard is completely discharged, and $\mathrm{N}_{2}$ in off-gas originates from top-blown oxygen flow, and $\mathrm{N}_{2}$ concentration in oxygen flow is $1 \%$.

Fig. 8 shows the changes of off-gas flowrate during blowing oxygen under two operation models of oxygen lance height. Offgas flowrate rapidly increases in the range of $0-20 \%$ blowing oxygen time, and keeps relatively stable in the range of $20-80 \%$ blowing oxygen time. Converter off-gas originates from the decarburization reaction. At the beginning of blowing oxygen, since the oxidization reaction rates of silicon and manganese are larger than that of carbon, oxygen blown is mainly consumed to oxidize silicon and manganese, and thus the off-gas flowrate is low. With the rapid decrease of silicon and manganese concentrations in molten metal bath and the increase of molten metal bath temperature, the decarburization reaction rapidly accelerates, and then a large amount of off-gas is produced. With the stabilization of decarburization reaction, the formation of off-gas keeps relatively stable. At the end of blowing oxygen, the decarburization reaction in molten metal bath nearly ends, and thus off-gas flowrate is low.

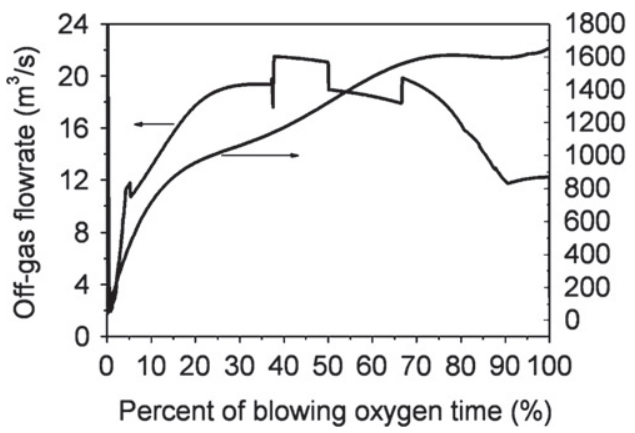

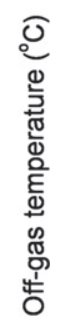

(a) Under operation model A

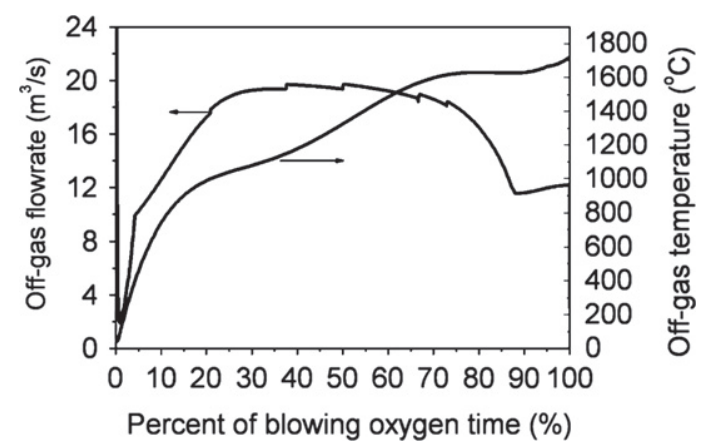

(b) Under operation model B

Fig. 8. The changes of off-gas temperature and flowrate during blowing oxygen.
The simulation results of off-gas flowrate indicate that the dramatic changes of oxygen lance height result in significant fluctuations of off-gas flowrate under operation model A, as shown in Fig. 8a. The oxygen lance height in converter influences the depth and area of the cavity. Consequently, the area of decarburization reaction varies with oxygen lance height, and thus the production amount of off-gas changes. With the decrease of oxygen lance height, the off-gas flowrate increases. The oxygen lance height of operation model $B$ gradually decreases, the off-gas flowrate changes gently as compared to that of operation model A, as shown in Fig. 8b.

The off-gas temperature monotonically increases with blowing oxygen time, and it reaches over $1600^{\circ} \mathrm{C}$ at the end of blowing oxygen, as shown in Fig. 8.

The sensible heat of off-gas is potential energy in the form of thermal energy. Since off-gas temperature of converter is high, off-gas has a large amount of sensible heat. Off-gas sensible heat can be recovered by cooling stack or waste heat boiler. Owing the frequent changes of off-gas sensible heat during steelmaking, the fatigue breakdown of heating surfaces of waste boiler easily occurs. Therefore, the changes of off-gas sensible heat during blowing oxygen are important for sensible heat utilization. The quantity of off-sensible heat flux is the product of the off-gas flowrate, its specific heat and its temperature above a reference temperature. For waste heat recovery, the reference temperature is $150{ }^{\circ} \mathrm{C}$. Off-sensible heat flux ( $q_{\text {off }}$ ) can be calculated by:

$q_{\text {off }}=f_{\text {off }} c_{\mathrm{v}}\left[T_{\text {off }}-T_{\text {re }}\right]$

where $f_{\text {off }}$ is off-gas flowrate, $\mathrm{m}^{3} / \mathrm{s} ; c_{\mathrm{v}}$ is the constant-volume specific heat of off-gas $\mathrm{J} /\left(\mathrm{m}^{3}{ }^{\circ} \mathrm{C}\right) ; T_{\text {off }}$ and $T_{\text {re }}$ are off-gas temperature and the reference temperature, respectively, ${ }^{\circ} \mathrm{C}$.

$f_{\text {off }}=\frac{22.4}{1000} \times F_{\text {out }}$

$c_{\mathrm{v}}=\sum_{i=1}^{4} c_{\mathrm{v}, i} c_{i} / 100 \quad i=\mathrm{CO}_{2}, \mathrm{~N}_{2}, \mathrm{O}_{2} \mathrm{CO}$

where $c_{\mathrm{v}, i}$ is the constant-volume specific heat, $\mathrm{J} /\left(\mathrm{m}^{3}{ }^{\circ} \mathrm{C}\right) ; c_{i}$ is the gas concentration, \%.

In order to express the variation extent of sensible heat flux during blowing oxygen, the percent of sensible heat flux $\left(\tilde{q}_{\text {off }}\right)$ is defined as:

$\tilde{q}_{\text {off }}=\frac{q_{\text {off }}}{q_{\max }} \times 100 \%$

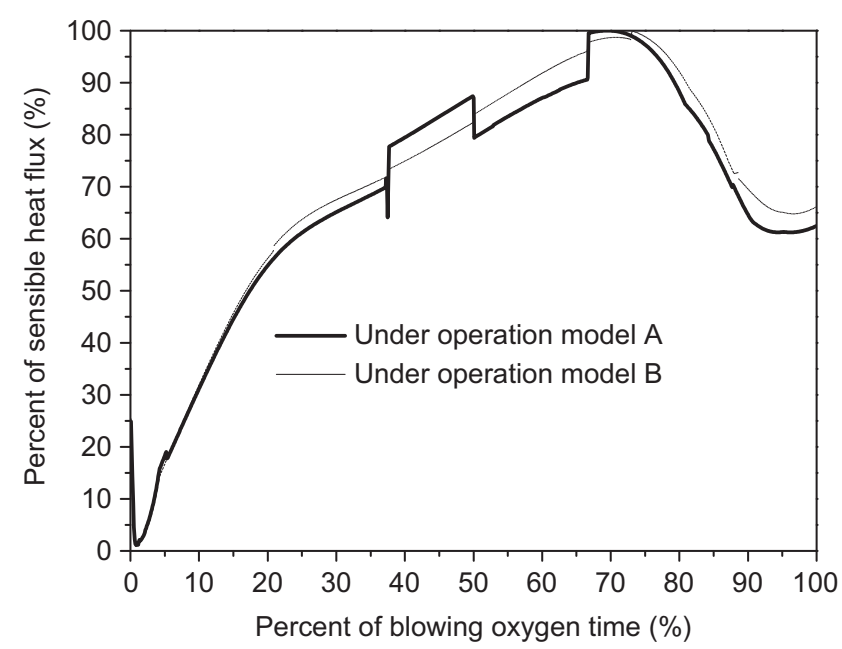

Fig. 9. The changes off-gas sensible heat during blowing oxygen. 


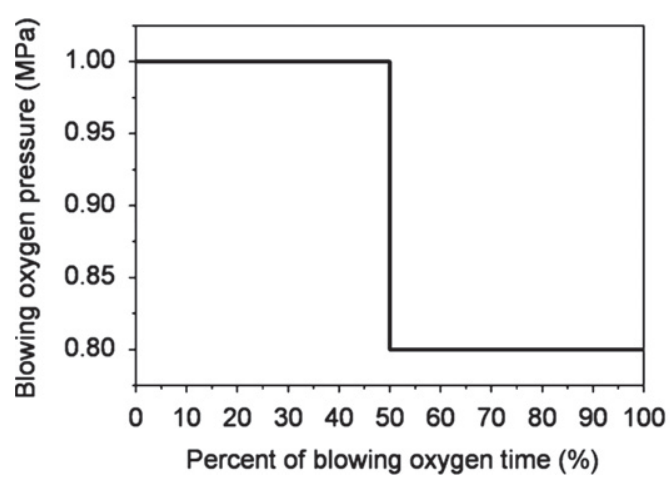

(a) Operation model A

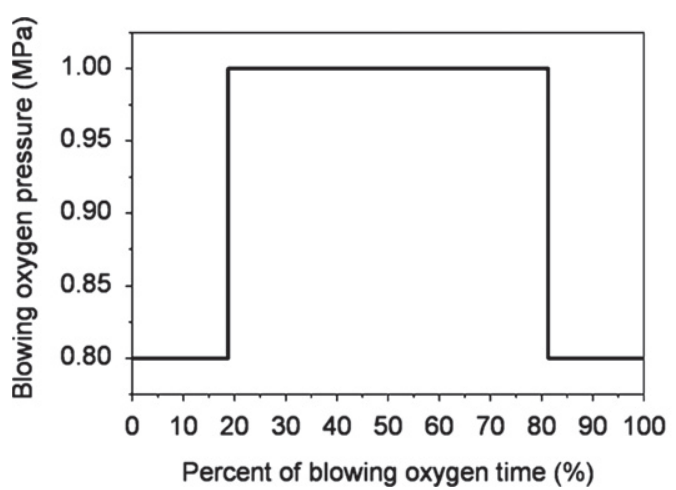

(c) Operation model $\mathrm{C}$

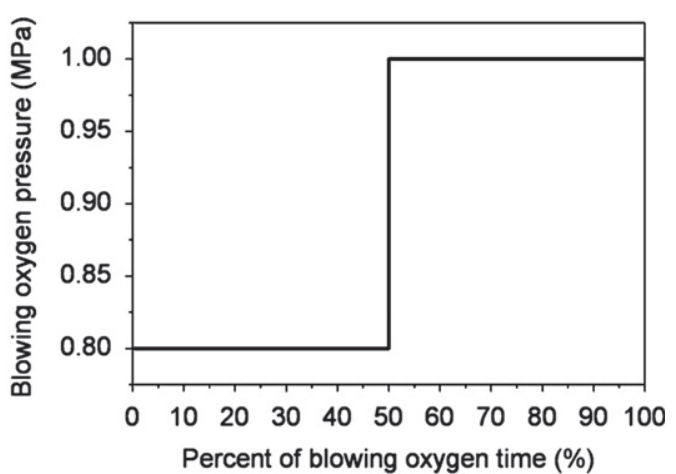

(b) Operation model B

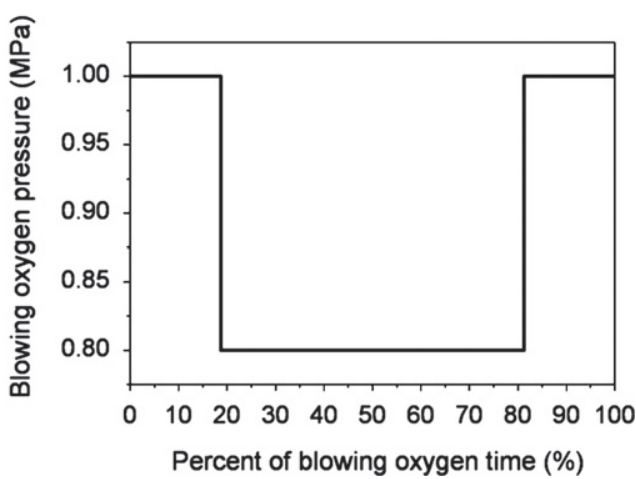

(d) Operation model D

Fig. 10. Operation models of blowing oxygen pressure.

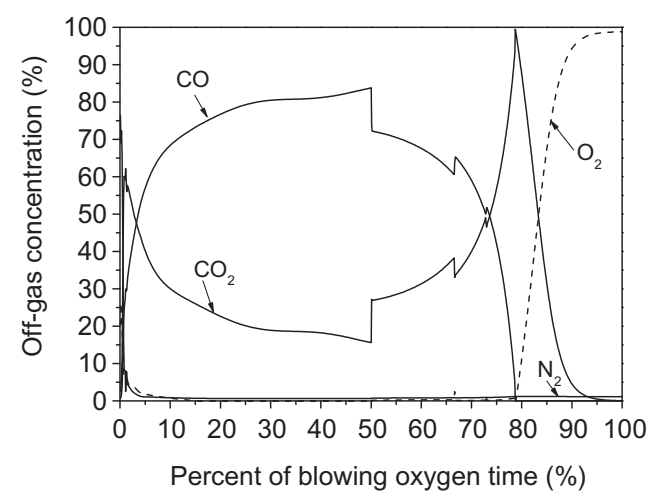

(a) Under operation model A

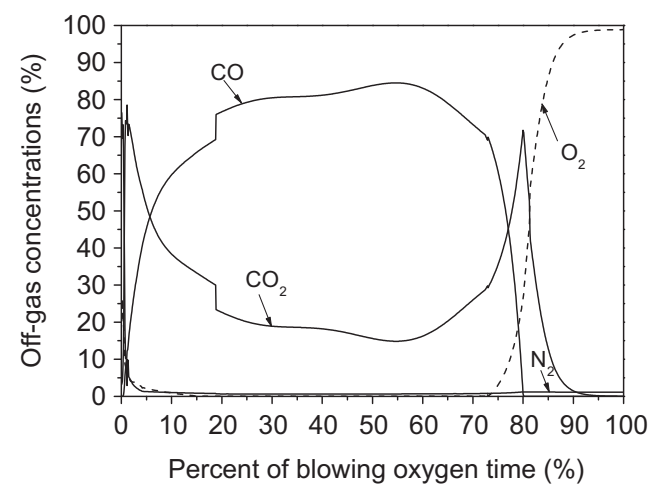

(c) Under operation model C

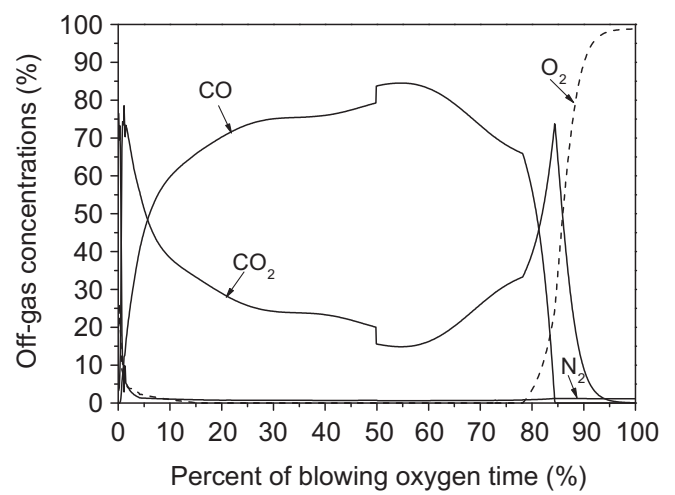

(b) Under operation model B

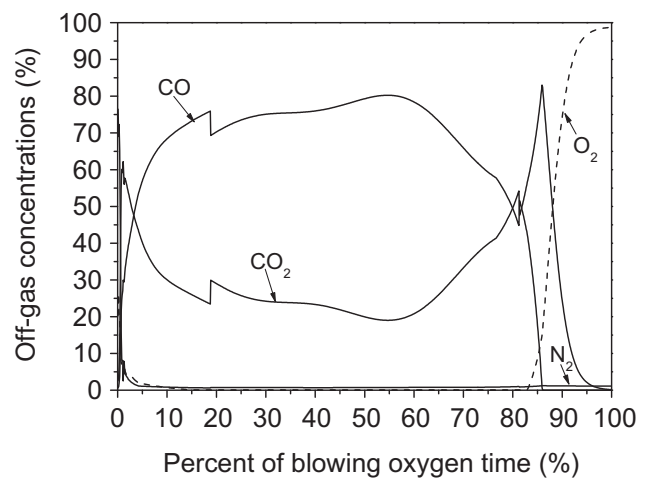

(d) Under operation model D

Fig. 11. The changes of converter off-gas concentrations during blowing. 


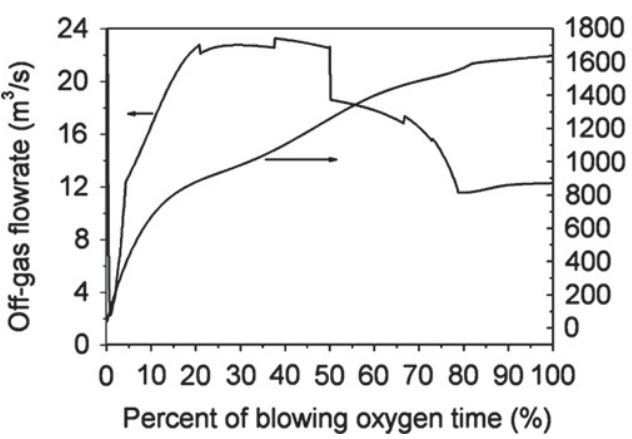

(a) Under operation model A

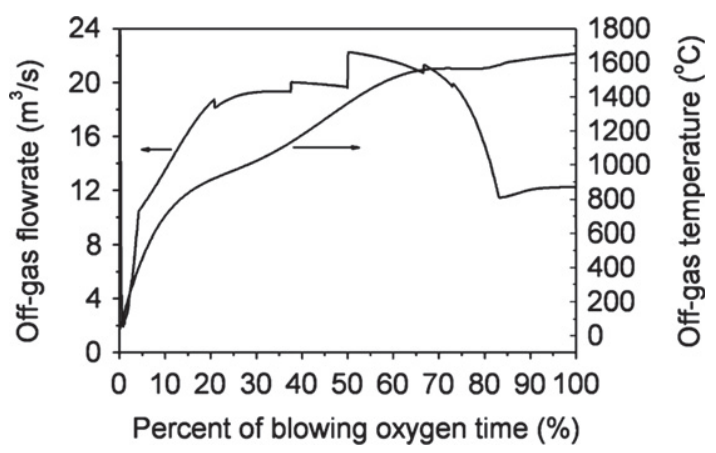

(b) Under operation model B

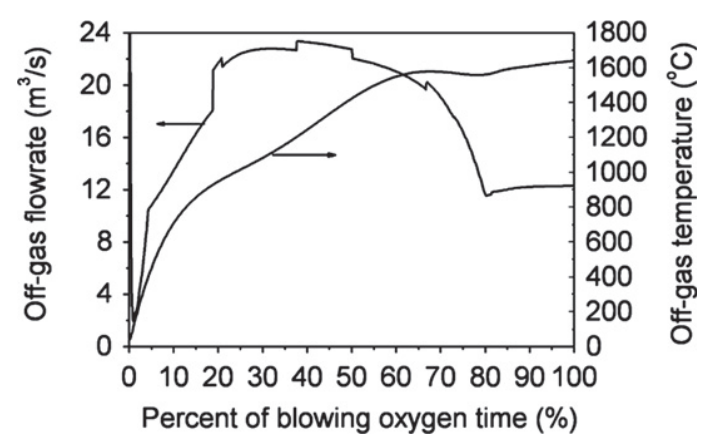

(c) Under operation model C

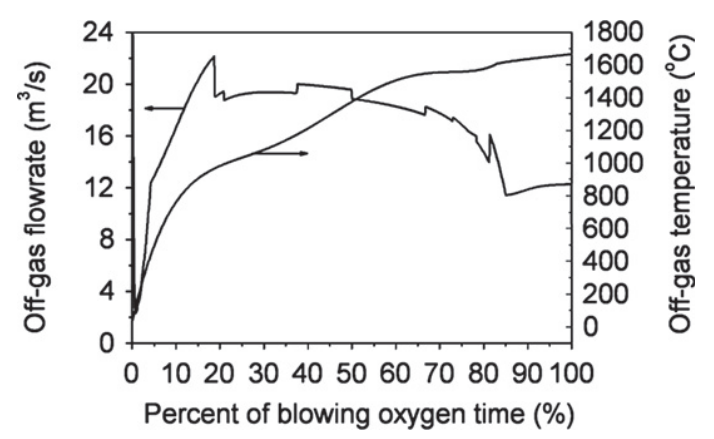

(d) Under operation model D

Fig. 12. The changes of off-gas temperature and flowrate during blowing oxygen.

where $q_{\max }$ is the maximum sensible heat flux.

Fig. 9 shows off-gas sensible heat flux change during blowing under two operation models of blowing oxygen lance height. The sensible heat flux rapidly increases when the blowing oxygen time varies from $0 \%$ to $20 \%$. The maximum sensible heat flux occurs at about $70 \%$ of blowing oxygen time, and the dramatic changes of
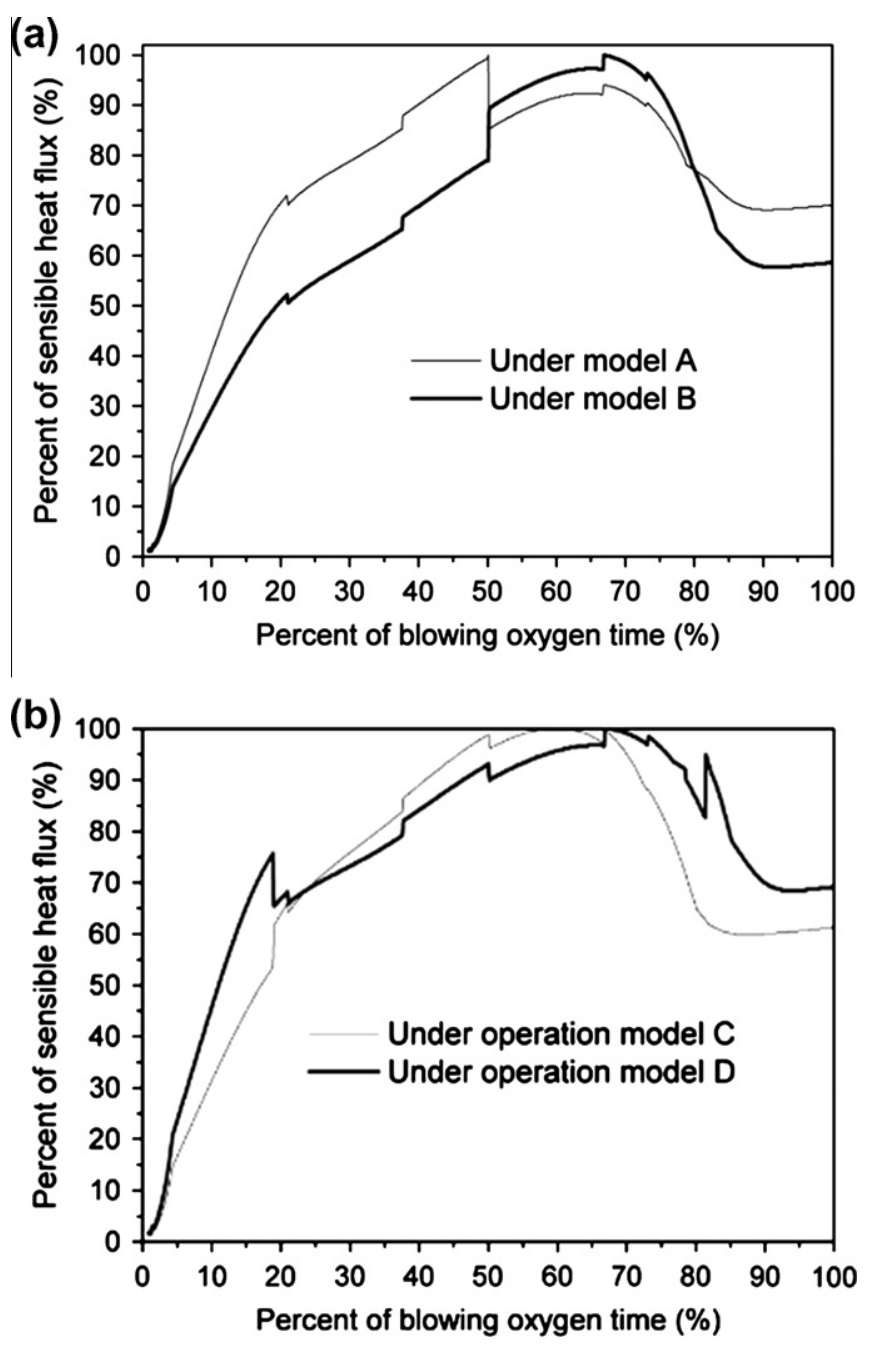

Fig. 13. The rate of off-gas sensible heat change during blowing oxygen.

oxygen lance height result in the noticeable fluctuations of sensible heat flux, as shown in Fig. 9. The sensible heat of converter off-gas can be utilized by waste boiler. The change of off-gas sensible heat results in the fluctuation of vapor pressure and steam output of waste boiler. The change curve of off-gas sensible heat flux is crucial to the heating surface design of waste boiler. In order to ensure the stability and safety of waste boiler, in the design of waste boiler, the choices of vapor pressure and water circulation ratio should be based on the change curve of off-gas sensible heat flux.

\subsection{The influences of oxygen-blowing pressure on the off-gas performances}

In the practical converter operation, at given throat cross-section of Laval nozzle and stagnation temperature of oxygen, the blowing oxygen flowrate is determined by the oxygen pressure through adjusting the oxygen valve, and the blowing oxygen flowrate is proportional to the 0.5 power the oxygen-blowing pressure. In order to effectively control decarburization rate and molten metal bath temperature, oxygen-blowing pressure is often adjusted. In the paper, under given B operation model of oxygen lance height (see Fig. 6b), the influence of the operation models of oxygenblowing pressure on converter off-gas performances is simulated, and four representative operation models of oxygen-blowing pressure are shown in Fig. 10. 
Fig. 11 shows the changes of converter off-gas concentrations during blowing oxygen under A, B, C and D operation models of oxygen-blowing pressure. The simulation results indicate that the changes of oxygen-blowing pressure have great influences on converter off-gas concentrations in the middle and late stages of blowing oxygen. As can be seen from Figs. 10-13, the rapid change of oxygen pressure causes the drastic changes of the decarburization rate, off-gas temperature and flowrate.

At the beginning of blowing oxygen, the oxygen mainly reacts with highly reactive elements (silicon and manganese), and thus the change of blowing oxygen flowrate by adjusting oxygen-blowing pressure has relatively little effect on the carbon oxidization. In the middle of blowing oxygen, high-temperature of molten metal bath and high carbon content are conducive to decarburize, and the limiting factor of decarburization reaction is oxygen mass transfer. High oxygen-blowing pressure enlarges the cavity surface area and increases the blowing oxygen intensity, and thus the decarburization reaction area and mass transfer are increased. Consequently, more $\mathrm{CO}$ is formed, and little excessive $\mathrm{O}_{2}$ reacts with $\mathrm{CO}$ in the furnace freeboard space to form $\mathrm{CO}_{2}$. Therefore, with the increases of oxygen-blowing pressure, $\mathrm{CO}$ concentration increases, and $\mathrm{CO}_{2}$ concentration decreases, as shown in Fig. 11. Owing to low carbon content in molten metal bath at the end stage of blowing oxygen, the increase of oxygen-blowing pressure can result in a large amount of excess $\mathrm{O}_{2}$ in the freeboard space, and $\mathrm{CO}$ rapidly is oxidized to form $\mathrm{CO}_{2}$.

In comparison Fig. 11a with Fig. 11b, high oxygen-blowing pressure in earlier stage results in high $\mathrm{CO}$ concentration and low $\mathrm{O}_{2}$ concentration. Therefore, under $\mathrm{A}$ operation model of oxygenblowing pressure (see Fig. 10a), $\mathrm{CO}$ and $\mathrm{O}_{2}$ concentrations can fast meet the restricted condition of converter off-gas recovery, and the off-gas can be earlier recovered, which may increase the off-gas recovery time. In comparison Fig. 11c with Fig. 11d, high oxygenblowing pressure in the middle stage results in high $\mathrm{CO}$ concentration. Therefore, under $C$ operation model of oxygen-blowing pressure (see Fig. 10c), converter off-gas recovery is very safe, and offgas recovered is high quality.

Fig. 12 shows the influences of operation models of oxygen-blowing pressure on converter off-gas temperature and flowrate. The simulation results indicate that oxygen-blowing pressure significantly influences on converter off-gas flowrate. High oxygen-blowing pressure makes blowing oxygen intensity and decarburization rate increase, and thus a large amount of off-gas is produced. The sudden change of off-gas flowrate caused by adjusting the oxygen pressure is very dangerous to off-gas combustion or recovery system. In the practical steelmaking process, the dramatic change of off-gas flowrate may results in the significant fluctuation of off-gas pressure around the interspace between the mobile smoke cover and the converter mouth, and thus off-gas leakage or air inleakage easily occurs, which causes pollute environment or off-gas explosion. Therefore, in order to ensure the stability and safety of off-gas recovery during blowing oxygen, the adjustment argument of oxygen pressure should be small.

In the practical blowing oxygen process, off-gas entrains large amounts of flue dust, and the heating surface of waste heat boiler is easily abraded. Therefore, based on the maximum off-gas flowrate during blowing oxygen, in the design of waste boiler, the choice of off-gas velocity is very important, and off-gas velocity should be less than $13-18 \mathrm{~m} / \mathrm{s}$.

The influence of operation models of oxygen-blowing pressure on off-gas temperature is not obvious, as shown in Fig. 12. Offgas temperature monotonically increases with blowing oxygen time, and it reaches over $1600{ }^{\circ} \mathrm{C}$ at the end of blowing oxygen.

Fig. 13 shows the influence of the operation models of oxygenblowing pressure on the sensible heat flux of off-gas during blowing oxygen. The simulation results indicate that the operation models of oxygen-blowing pressure significantly influence off-gas sensible heat flux, and off-gas sensible heat flux is high at high oxygen-blowing pressure. In the range of $40-80 \%$ blowing oxygen time, the sensible heat is high.

\section{Conclusions}

The characteristics of 203 ton converter off-gas formation were investigated by numerical simulations, and the influences of the operation models of oxygen lance on the change characteristics of off-gas were studied. The comparison of the predicted and measured values of decarburization reaction indicates that the developed model can reasonably describe the production process of top-blown oxygen converter steelmaking. In the range of $10-80 \%$ blowing oxygen time, $\mathrm{CO}$ concentration varies gently, and its maximum value can reach about $80 \%$. The possibility of the explosion of off-gas exists during off-gas recovery when $\mathrm{O}_{2}$ concentration is larger than $1 \%$ in the ranges of $0-15 \%$ and $80-100 \%$ blowing oxygen time. The maximum sensible heat flux occurs at about $70 \%$ of blowing oxygen time, and the dramatic change of oxygen lance position results in a noticeable fluctuation of sensible heat. The changes of oxygen-blowing pressure have great influences on converter off-gas concentrations in the middle and late stages of blowing oxygen time.

\section{Acknowledgements}

Financial supports by National Natural Science Foundation of China (No. 50976123, No. 50976122) and the Knowledge Innovation Program of the Chinese Academy of Sciences (No. KGCX2-YW-321).

\section{Appendix A. Supplementary data}

Supplementary data associated with this article can be found, in the online version, at doi:10.1016/j.fuel.2011.01.022.

\section{References}

[1] Aleksashin AL, Schnaltzger I, Hollias G. Creation and growth of oxygenconverter steelmaking. Metallurgist 2007;51:60-5.

[2] Ramaseder, N. Technological developments in oxygen converter steelmaking. <http://www.allbusiness.com/primary-metal-manufacturing/iron-steel-millsferroalloy/297604-1.html>

[3] Perlov N, Nitskevich E. Efficient use of converter gas. Metallurgist 1965;3:21-2.

[4] Maruoka N, Akiyama T. Energy recovery from steelmaking off-gas by latent heat storage for methanol production. Energy 2006;31:10-1.

[5] Akiyama T, Oikawa K, Shimada T, Kasai E, Yagi JI. Thermodynamic analysis of thermochemical recovery of high temperature wastes. ISIJ Int 2000;40:286-91.

[6] Bada H, Yamada S, Yaji M, Sudo F, Kodaka M. Improvement in off-gas recovery from Q-BOP. Kwasaki Steel Tech Rep; 1983.

[7] Wang AH, Cai JJ, Li XP, Wang D, Zhou QA. Affecting factors and improving measures for converter gas recovery. J Iron Steel Res, Int 2007;14:22-6.

[8] Asai S, Muchi I. Mathematical model of oxygen top blowing converter. Iron Steel Ins Jpn (ISIJ) 1969;55:122-32 (in Japanese).

[9] Tang Y, Fabritius T, Härkk J. Mathematical modeling of the argon oxygen decarburization converter exhaust gas system at the reduction stage. Appl Math Model 2005;29:497-514.

[10] Tang P, Yu YY, Wen GH, et al. Study on the optimization of the combined blown converter process in Chongqing iron and steel company. J Univ Sci Technol, Beijing 2008;15:5-9.

[11] Gou H, Irons GA, Lu WL. Mathematical modeling of post combustion in a KOBM converter. Metall Trans B 1993;24:179-88.

[12] Wei JH, Zhu DP. Mathematical modeling of the argon-oxygen decarburization refining process of stainless steel. Part I: Mathematical model of the process. Metall Mater Trans B 2002;33:111-9.

[13] Barao CD, Silva CAD, Silva IAD. Analysis of parameters affecting end blow manganese content at oxygen steelmaking. Rev Metall 2008;105:556-61.

[14] Zong JH, Yoon JK. Theoretical interpretation of the decarburization mechanism in converter oxygen steelmaking. Metall Trans B-Process Metall 1990;21:49-57.

[15] Li BK. Metallurgical application of advanced fluid dynamics. Beijing: Metallurgical Industry Press; 2004. 
[16] He JH. Design principle of steelmaking. Beijing: Chemical Industry Press; 2008 (in Chinese).

[17] Basic oxygen steelmaking. <http://www.answers.com/topic/basic-oxygenprocess>.

[18] Meradi H, Bouhouche S, Lahreche M. Prediction of bath temperature using neural networks. World Acad Sci, Eng Technol 2006;24:120-4.

[19] Poferl J. Dynamic refining LD converter. Iron Steel Ins Jpn (ISIJ) 1988;28:59-67.

[20] Ermolaev AOA, Maier LG, Mosiyanov BI, Beitelman LS. Automatic control of the rate of decarburization in the converter bath. Metallurgist 1966;6:20-1.
[21] Odenthal HJ, Vogl N. Fire tests for molten metal converters. ANSYS Adv 2007;1:30-1.

[22] Dai YG. Modern converter steelmaking. Shenyang: Northeast University Press; 1998 (in Chinese).

[23] Ma H. Numerical simulation of steelmaking process with combined-blown converter. Shenyang: Northeastern University; 2003.

[24] Miwa M, Asai S, Muchi I. Mathematical model of LD converter process taken account of oxidation of phosphorus and manganese of rate of lime solution Iron Steel Ins Jpn (ISIJ) 1970;56:1677-86 (in Japanese). 